\title{
Bioactive compounds and medicinal properties of fruit juices
}

\author{
Raju Lal BHARDWAJ ${ }^{1}$, Urvashi NANDAL ${ }^{2 *}$, Ajay PAL ${ }^{3}$, Shashi JAIN ${ }^{4}$
}

1 Dep. Hortic., Maharana Pratap Univ. Agric. Technol., Post Box 15, Krishi Vigyan Kendra, Sirohi 307001

(Rajasthan), India,

rajubhardwaj3@gmail.com

2 Dep. Foods Nutr., Krishi Vigyan Kendra, Rajsamand, MPUAT, Udaipur (Rajasthan), India,

nandalu@rediffmail.com

${ }^{3}$ Dep. Biochem., COBS, CCSHAU, Hisar (Haryana), India

${ }^{4}$ Dep. Foods Nutr., COHS, MPUAT, Udaipur (Rajasthan), India

${ }^{*}$ Correspondence and reprints

Received October 8, 2013 Accepted February 27, 2014

Fruits, 2014 , vol. 69 , p. 391-412 (C) 2014 Cirad/EDP Sciences All rights reserved

DOI: 10.1051/fruits/2014027 www.fruits-journal.org

RESUMEN ESPAÑOL, p. 412

\section{Bioactive compounds and medicinal properties of fruit juices.}

Abstract - The product. Fruit juices have attained an important place in the modern diets of people belonging to different communities and classes world over. It is the unfermented but fermentable liquid obtained from the edible part of sound, appropriately mature and fresh fruit. Bioactive compounds. Fruit juices contain nutrients like vitamins, minerals, trace elements, energy and phytochemicals including flavonoids, polyphenols and antioxidants that have been shown to have varied health benefits. Medicinal properties. The mode of action of these fruit juice compounds in most cases seems to be by modulating gene activities. Fruit juice as part of a balanced diet offers both good health and profound disease risk reduction properties. As a result, there is high demand as alternative medicine for different kinds of illnesses such as chronic inflammation, arthritis, diabetes, high blood pressure, muscle aches and pains, menstrual difficulties, headaches, heart disease, AIDS, cancers, gastric ulcers, sprains, mental depression, poor digestion, arteriosclerosis, blood vessel problems, and drug addiction. Furthermore, to identify fruit juices as non-consumable in the context of obesity and dental health would deprive the consumer of a perfectly healthy and nutritious food, and would be completely contrary to the evidence noted in the scientific community. Discussion and conclusion. Fruit juices are an excellent choice of drink when consumed moderately as per recommendations.

India / fruits / fruit juices / health foods / medicinal properties / antioxidants / phytochemistry / resveratrol / overweight

\section{Composés bio-actifs et propriétés médicinales de jus de fruits.}

Résumé - Le produit. Les jus de fruits ont une place importante dans les régimes modernes de personnes appartenant à différentes communautés et classes du monde entier. Ce sont les liquides non fermentés, mais fermentescibles, tirés de la partie comestible des fruits sains et suffisamment mûrs et frais. Composés bio-actifs. Les jus de fruits contiennent des nutriments comme les vitamines, les éléments minéraux, les oligo-éléments, de l'énergie et des composés phytochimiques, y compris des flavonoïdes, des polyphénols et des antioxydants démontrés comme présentant des avantages de santé variés. Les propriétés médicinales. Le mode d'action des composés bio-actifs à base de jus de fruit dans la plupart des cas semble être lié à la modulation des activités des gènes. Dans le cadre d'une alimentation équilibrée, les jus de fruit permettent à la fois d'avoir une bonne santé et de limiter sérieusement les risques de maladie ; il y a donc une forte demande par la médecine alternative pour lutter contre différents types de maladies tels que inflammations chroniques, arthrite, diabète, hypertension artérielle, douleurs musculaires, douleurs menstruelles, maux de tête, maladies cardiaques, sida, cancers, ulcères gastriques, entorses, dépression, mauvaises digestions, artériosclérose, problèmes sanguins, et toxicomanie. En outre, considérer les jus de fruits comme non-consommables dans le contexte de l'obésité et de la santé dentaire priverait le consommateur d'une denrée alimentaire parfaitement saine et nutritive, et serait tout à fait contraire aux informations données par la communauté scientifique. Discussion et conclusion. Les jus de fruits, consommés modérément en suivant certaines recommandations, constituent un excellent choix de boisson.

Inde / fruits / jus de fruits / aliment santé pour homme / propriété pharmacologique / antioxydant / phytochimie / resvératrol / surpoids 


\section{Introduction}

Fruit juices have attained an important status in the daily menu of people belonging to different ages, classes, groups and areas because of their exceptional nutritional, functional and therapeutic qualities [1]. Minerals are present in the form of electrolytes so they are easily absorbable by the human body $[2,3]$. They are considered to be rich in diverse sources of vital nutrients which include vitamins like A, B, C, folate [3, 4]; minerals like iron, copper, potassium, iodine, zinc, selenium, iodine, sulfur, manganese, boron, molybdenum and magnesium [5]; dietary fiber and antioxidants, amino acids, and bioactive compoundsphytonutrients [4] which are crucial for good nutrition, disease prevention and offer great taste and health benefits [6, 7]. Pure fruit juice is an important source of fluids and a wonderful resource for enzymes (papain in papaya juice, bromelin and proteolytic enzymes in pineapple juice). As juices are consumed fresh $[2,8]$, they are an excellent way to retain and balance hydration levels in the body [9]. Fruit juices are readily digestible; they have no toxic effects on the body and exert a cleansing effect on the blood and digestive tract; they facilitate absorption of certain nutrients [10]. The low level of sodium in fruit juices plays an important role for people who would like to have a salt-free diet [9]. Moreover, the ailments caused by the intake of unnatural foods can be successfully treated by them as they promote detoxification in the human body [11].

Fruit juices in the daily diet have been strongly associated with reduced risk of some forms of cancer [12, 13], cardiovascular disease [14, 15], positive effect on bone health [16, 17] and skin related problems [18], allergies, gastrointestinal problems, hyperlipidemia, insulin resistance, oxidative stress, inflammation [19], dental health [20], brain health, cognition and ageing [21, 22], and other chronic diseases.

Fruit juices also prevent the formation of kidney and gall stones, due to their potassium salt richness and are recommended in acidosis, diabetes, under-nutrition, gout, and ageing tissues [11]. Antioxidant capacity varies greatly among fruit juices so it is better to consume a variety of them [23]. They reduce unwanted fat, cure ulcers, regulate digestion, have inhibitory effects against the HIV virus and promote metabolic functions [24]. Various juice blends (mixed fruit juices) fortified with calcium, folate, fiber and vitamins have been launched for improving palatability, and nutritional and medicinal quality of fruit juices on the market [8, 25]. Also worldwide, health concerns have led to the popularization of natural fruit juice as a healthy alternative to other beverages and carbonated soft drinks, which have high artificial sugar levels [26, 27]. Previously, fruits were directly consumed by health-conscious people, but in today's era of changing lifestyles, modified eating habits and in view of seasonal availability, people have shifted towards nutritious ready-to-eat or to serve products like fruit juices [5, 28].

\section{General dietary recommendations for fruit juice}

Considerable interest in fruit juices has been developed over the years due to their potential biological and health-promoting effects $[6,27]$. According to the new USDA My Pyramid food guidance program, there are portion sizes and recommended amounts of 100 per cent fruit juices for children and adults, depending on one's age, gender, and level of physical activity [29]. The scientific findings showed that consuming a variety of fruit juices (100 $\mathrm{mL}$ per day or more) has the potential to decrease numerous chronic diseases like cancer, inflammation and cardiovascular diseases [30]. People with higher socio-economic status often report higher consumption of fruit juice as compared to lower ones [28, 31].

The World Health Organization (WHO) as a co-sponsor of the global $5+$ a day program promotes the inclusion of at least five servings a day of fruits and vegetables as an essential element in a healthy diet [32]. Many countries have considered fruit juices as one portion of the daily fruit and vegetable intake, to be a constituent of 5+ a-day 
campaigns or national dietary recommendations [33]. The UK National Diet and Nutrition Survey reported average consumption of fruit juices as $106 \mathrm{~g}$ per day, with men consuming slightly more than women. The American Academy of Pediatrics (AAP) suggests $100-150 \mathrm{~mL}$ of 100 per cent fruit juice per day for children aged 1 to 6 years, and up to $150-200 \mathrm{~mL}$ per day for children aged 7 to 18 years. No juices are recommended for infants less than 6 months of age [34].

Eating too much fruit juice may result in some intestinal discomfort, flatulence, obesity, diabetes mellitus and tooth decay, because fruit juice contains a small amount of sorbitol, a sugar alcohol which the body cannot process but bacteria in the digestive system can break down for energy [34].

\section{Interaction mechanism of fruit juice components in the human body}

Polyphenolic compounds in fruit juices are known for their antioxidant properties and play an important role in interaction of metabolic activities in the human body as therapeutic agents $[35,36]$. Although here it is impossible to explain the interaction mechanisms of all fruit juice phenolic compounds, a sincere effort has been made to briefly summarize the recent information pertaining to the beneficial roles of one of the highly studied and important phenolic compounds, namely resveratrol and its interaction mechanisms in the human body with respect to its neuroprotective effect.

Research has described several beneficial properties of this compound, including anti-carcinogenic, anti-ageing, neuroprotective, analgesic, anti-diabetic and antiobesity effects [37] and is synthesized by leaf tissues in response to fungal infection or exposure to ultraviolet light [38]. Resveratrol (trans-3, 4', 5-trihydroxystilbene) (figure 1) is a polyphenolic molecule found in many plant species including grapes, cranberries, bael, pomegranate, aonla and citrus fruit juices.

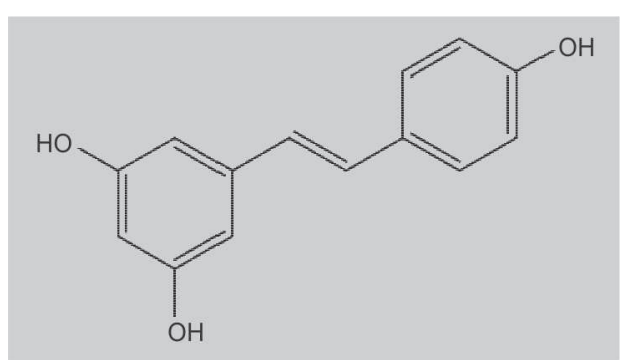

Figure 1.

Structure of resveratrol, the most important and effective bioactive compound of fruit juice on which maximum research and studies have been done.

\subsection{Bioavailability and pharmacokinetics of resveratrol}

A number of studies have shown that bioavailability of unconjugated resveratrol is low. At least $70 \%$ of resveratrol ingested is absorbed and readily metabolized to form mainly glucuronide and sulfate derivatives [39]. The colon microflora can produce the metabolite dihydroresveratrol. Resveratrol metabolites reach their maximum concentration in plasma approximately $30 \mathrm{~min}$ after intake and the half-life of total metabolites is approximately 9.2 hours [40]. Five distinct metabolites have been detected in urine after moderate consumption of red wine: resveratrol monosulfate, two isomeric forms of resveratrol monoglucuronide, dihydroresveratrol monosulfate and dihydroresveratrol [41]. It is also worth mentioning that resveratrol binds to albumin and therefore it has been suggested that albumin could be a natural polyphenol reservoir in the in-vivo context, where it might play a pivotal role in the distribution and bioavailability of circulating resveratrol [42].

\subsection{Molecular mechanisms of the neuroprotective effects of resveratrol}

A number of studies have demonstrated the beneficial effects of resveratrol through its antioxidant, anti-inflammatory and metalchelating properties [43, 44]. However, another study has revealed that the ability of resveratrol to exert neuroprotective effects is through activation of Sirt1 [45]. Activation of Sirt1 through resveratrol induces PGC- $1 \alpha$ activity and enhances mitochondrial function. PGC-1 $\alpha$ [peroxisome proliferator-activated receptor $\gamma$ (PPAR $\gamma$ ) 
coactivator-1] is a transcriptional coactivator and interacts with nuclear receptors and transcription factors [37, 46]. Once activated, PGC- $1 \alpha$ performs different functions in different tissues. Another protein named peroxisome proliferator-activated receptor- $\gamma$ (PPAR- $\gamma$ ) has been proposed as a therapeutic target for neurodegenerative diseases due to its ability to protect against mitochondrial damage through upregulation of $\mathrm{Bcl}-2$, an anti-apoptotic protein [47]. There are reports which suggest that resveratrol's ability to attenuate tissue injury in the brain and restore mitochondrial function is partly attributed to its effect on Sirt1-dependent deacetylation of PGC- $1 \alpha$ and activation of PPAR- $\gamma[12,48]$.

Activation of PPAR- $\gamma$ may also target the transcription of superoxide dismutase (SOD) and catalase genes through stimulating the Nrf2/keap 1 pathway [49]. Thus, it can be hypothesized that the ability of resveratrol to increase Sirt1 and related enzyme activity could lead to changes in neuronal transcription profiles and enhanced antiapoptotic activities [50]. A number of studies have also demonstrated the ability of resveratrol to reduce amyloid-beta (A $\beta$ ) peptide secretion [51] and suppress neuroinflammation by inhibiting NADPH oxidase and attenuating NF- $\mathrm{\kappa B}$-induced expression of iNOS, COX-2, and SPLA2 [52, 53].

Resveratrol also stimulates mitochondrial biogenesis that has been shown to be dependent on AMP-kinase (AMPK) [37, 45]. The neuronal activation of AMPK could affect neuronal energy homeostasis and contribute to the neuroprotective effects of resveratrol. The net effect of AMPK activation is to halt energy consuming (anabolic) pathways and to promote energy conserving (catabolic) cellular pathways. AMPK has, therefore, often been dubbed the 'metabolic master switch'. Increasing evidence suggests that AMPK might also function as a sensor by responding to oxidative stress. Most importantly, AMPK modulates endogenous antioxidant gene expression and/or suppress the production of oxidants. AMPK promotes cardiovascular homeostasis by ensuring an optimum redox balance on the heart and vascular tissues. Taken together, it can be concluded that besides its antioxidant and anti-inflammatory properties, resveratrol also exerts neuroprotective effects through activation of Sirt1 [54, 55].

This evidence makes resveratrol a promising therapeutic candidate for neurodegenerative disorders. Resveratrol has also been regarded as a cancer chemopreventive agent. The studies have demonstrated the antioxidant effect of resveratrol, its ability to counteract ROS production and thus to inhibit oxidative DNA damage. Evidence is growing that suggests that resveratrol may also act as a pro-oxidant and can cause induction of apoptosis of cancer cells [56].

\section{Bioactive compounds of fruit juices}

\subsection{Nutrients}

There is not much difference between fruit and fruit juice in the proximate composition and nutritional properties [2, 4]. The relevant substance groups are carbohydrates, watersoluble vitamins, minerals (potassium, calcium and magnesium), organic acids, amino acids, fibers and polyphenols like colorful anthocyanins, aroma compounds, carotenoids and other bioactive substances [26]. Fruit juices are also important sources of certain vitamins, especially vitamins A, B and $\mathrm{C}$ which act as antioxidants, prevent undesirable color changes and retard the development of rancidity. Vitamin A precursors like $\beta$-carotene and certain carotenoids are present in the yellow-orange fruit juices like mango, papaya, pineapple, orange, passion fruit, phalsa, tomato, raspberry and muskmelon juice [11]. Vitamin B complex and folate are present in orange, grapefruit, pineapple and other tropical fruit juices $[57,58]$. Aonla, ber, noni, barbados cherry, tomato, guava, kiwifruit, orange, lemon, lime, strawberry, grape fruit, mango, pineapple, cherry and passion fruit juices contain a large amount of vitamin C [58, 59].

Fruit juices are known to store considerable amount of organic acids. Lemon and orange juice contains citric acid and ascorbic acid; apple, gooseberry and rhubarb juice contains malic acid; grape and tamarind juice contains tartaric acid; aonla juice and 
ber juice contains gallic and ascorbic acid; tomato juice contains ascorbic acid, and carambola juice is rich in oxalic acid [60]. Other organic acids present in minor amounts are lactic acid, succinic acid, pyruvic acid, glyceric acid, shikimic acid, maleic acid and isocitric acid. Juices are low in compounds such as sodium and fat which are believed to have negative health impacts when ingested in large amounts [9, 57].
Many trace elements ( $\mathrm{Zn}, \mathrm{Fe}, \mathrm{Cu}, \mathrm{Mn}$, $\mathrm{Co}, \mathrm{Cr}$, and $\mathrm{Ni}$ ) present in fruits are also found in the corresponding fruit juices [5]. In addition, juices may serve as carriers for added nutrients such as calcium, vitamin C and phytosterols that may not be inherent in the fruit itself [2]. We discussed the proximate nutrient composition of various fruit juices (table I) and their positive effect on human wellness (table II).

Table I.

Proximate nutrient composition of various fruit juices (nutrients in $100 \mathrm{~mL}$ fruit juice) [58].

\begin{tabular}{|c|c|c|c|c|c|c|c|c|}
\hline Fruit juice & $\begin{array}{l}\text { Water } \\
(\mathrm{mL})\end{array}$ & $\begin{array}{l}\text { Energy } \\
\text { (kcal) }\end{array}$ & $\begin{array}{l}\text { Available } \\
\text { carbone } \\
\text { (g) }\end{array}$ & $\begin{array}{c}\text { Beta carotene Eq } \\
(\mu \mathrm{g})\end{array}$ & $\begin{array}{l}\text { Vitamin C } \\
(\mathrm{mg})\end{array}$ & $\begin{array}{l}\text { Folate } \\
(\mu \mathrm{g})\end{array}$ & $\begin{array}{l}\text { Calcium } \\
\text { (mg) }\end{array}$ & $\begin{array}{l}\text { Potassium } \\
\quad(\mathrm{mg})\end{array}$ \\
\hline Aonla & 87.8 & 55.0 & 15.7 & 7.5 & 592.0 & 4.6 & 42.0 & 218.0 \\
\hline Apple & 88.9 & 52.5 & 10.1 & 0 & 1.0 & 0.0 & 8.2 & 81.0 \\
\hline Bael & 71.2 & 127.0 & 35.8 & 50.2 & 11.5 & 18.5 & 80.2 & 570.0 \\
\hline Banana & 73.1 & 120.0 & 29.2 & 70.5 & 7.3 & 1.5 & 17.0 & 80.5 \\
\hline Custard apple & 72.5 & 104.0 & 25.5 & 3.5 & 37.0 & 42.5 & 17.0 & - \\
\hline Grape & 85.5 & 71.5 & 13.4 & - & 13.7 & 2.3 & 18.5 & 45.8 \\
\hline Grapefruit & 91.4 & 42.5 & 6.0 & - & 61.0 & 5.0 & 12.0 & 100.0 \\
\hline Guava & 87.7 & 57.5 & 18.2 & 3.5 & 212 & 4.9 & 10.5 & 85.6 \\
\hline Lemon & 88.0 & 52.5 & 10.1 & 10.0 & 35.5 & 28.3 & 70.2 & 232.0 \\
\hline Lichi & 87.1 & 61.8 & 15.6 & 0.0 & 31.6 & 5.6 & 8.5 & 150.5 \\
\hline Lime & 86.6 & 55.2 & 10.9 & 15.0 & 65.1 & 27.5 & 90.5 & 160.5 \\
\hline Mango & 86.0 & 85.7 & 20.9 & 2700 & 15.5 & 15.2 & 14.0 & 195.0 \\
\hline Orange & 93.2 & 9.5 & 4.5 & 26.0 & 64.0 & 40.2 & 60.3 & 125.4 \\
\hline Papaya & 90.8 & 32.0 & 7.2 & 660.0 & 55.0 & 23.5 & 17.0 & 60.5 \\
\hline Passion fruit & 89.0 & 37.0 & 7.7 & 1968 & 13.0 & 2.5 & 10.0 & 12.5 \\
\hline Peach & 89.0 & 50.2 & 10.5 & 0.0 & 5.0 & 3.0 & 15.0 & 450.5 \\
\hline Pear & 88.0 & 50.5 & 11.9 & 20.5 & 4.5 & 5.3 & 8.5 & 96.8 \\
\hline Phalsa & 84.8 & 70.0 & 15.7 & 410.0 & 22.0 & 7.9 & 120.0 & 345.0 \\
\hline Pineapple & 92.5 & 38.4 & 10.3 & 11.5 & 32.3 & 8.0 & 15.3 & 65.0 \\
\hline Pomegranate & 82.0 & 85.0 & 16.5 & 35.0 & 16.0 & 14.5 & 10.0 & 133.0 \\
\hline Raspberry & 88.8 & 50.2 & 10.7 & 1240.0 & 30.0 & 37.5 & 40.0 & - \\
\hline Sapota & 78.7 & 95.0 & 21.4 & 90.5 & 6.0 & 5.4 & 22.5 & 260.8 \\
\hline Strawberry & 90.8 & 40.5 & 9.80 & 18.50 & 52.0 & 5.5 & 30.0 & 15.5 \\
\hline Tomato & 95.0 & 20.0 & 3.6 & 351.0 & 27.0 & 30.0 & 48.0 & 146.0 \\
\hline Water melon & 96.8 & 15.0 & 3.3 & 3.5 & 1.0 & 5.8 & 10.5 & 160.0 \\
\hline Wood apple & 68.2 & 130.0 & 18.1 & 6.5 & 3.5 & 17.0 & 130.0 & 25.0 \\
\hline Zizyphus & 85.6 & 78.0 & 22.0 & 21.0 & 76.0 & 15.5 & 4.0 & 25.9 \\
\hline
\end{tabular}


Table II.

Nutrient constituents of fruit juice having positive effects on human wellness [183].

\begin{tabular}{|c|c|c|}
\hline Constituent & Major sources of fruit juice & Effect on human wellness \\
\hline Protein & $\begin{array}{l}\text { Chilgoza, wood apple juice, currants, } \\
\text { korukkapalli, custard apple, grape, noni } \\
\text { and bael, etc. }\end{array}$ & $\begin{array}{c}\text { Proteins are the important constituent of tissues, muscles, cells of the } \\
\text { body and vital body fluids like blood. } \\
\text { Proteins in the form of enzymes, hormones and antibodies are } \\
\text { involved in metabolic processes. }\end{array}$ \\
\hline Carbohydrate & $\begin{array}{l}\text { Banana, bael, fresh dates, custard apple, } \\
\text { pomegranate, ber, papaya, mango, guava, } \\
\text { grape, orange, apple, etc. }\end{array}$ & $\begin{array}{l}\text { Important sources of energy, act as fibrous component of diet, help in } \\
\text { utilization of body fat, exert sparing effects on protein and necessary } \\
\text { for the mechanism of digestion and elimination of waste. }\end{array}$ \\
\hline Fats & $\begin{array}{l}\text { Maximum fruits are fat-free. } \\
\text { Mulberry, wood apple, guava, apple, etc. }\end{array}$ & $\begin{array}{c}\text { Concentrated sources of energy, reserve food material, sources } \\
\text { of essential fatty acids. } \\
\text { Prevention of phrynoderma (toad skin) disease. }\end{array}$ \\
\hline Energy & $\begin{array}{l}\text { Fresh dates, apple, grape, chilgoza, } \\
\text { currants, wood apple, bael, mango, } \\
\text { orange, pomegranate, etc. }\end{array}$ & Energy is essential for rest, activity and growth of the body. \\
\hline Vitamin A & $\begin{array}{l}\text { Mango, papaya, orange, bael, guava, } \\
\text { pomegranate, pineapple, etc. }\end{array}$ & $\begin{array}{c}\text { Prevention of night blindness, chronic fatigue, psoriasis, heart } \\
\text { disease, stroke, cataracts. }\end{array}$ \\
\hline $\begin{array}{l}\text { Vitamin } \mathrm{B}_{1} \\
\text { (thiamine) }\end{array}$ & $\begin{array}{l}\text { Chilgoza, korukkapalli } \\
\text { bilberry, cherry, apple, g }\end{array}$ & $\begin{array}{l}\text { Acts as anti beri-beri or anti-neuritic vitamin. } \\
\text { Deficiency of thiamine causes dropsy, palpitations and heart failure. }\end{array}$ \\
\hline $\begin{array}{l}\text { Vitamin } \mathrm{B}_{2} \\
\text { (riboflavin) }\end{array}$ & $\begin{array}{l}\text { Bael, papaya, pineapple, black berry, } \\
\text { bilberry, cherry, apple, goose berry, litchi, } \\
\text { etc. }\end{array}$ & $\begin{array}{l}\text { Inadequate intake of this vitamin in diet leads to soreness of tongue } \\
\text { (glossitis), cracking at the angles of mouth, redness and burning } \\
\text { sensation in the eyes. }\end{array}$ \\
\hline $\begin{array}{l}\text { Vitamin } \mathrm{B}_{3} \\
\text { (niacin) }\end{array}$ & $\begin{array}{l}\text { Litchi, chilgoza, mango, bael, grape, } \\
\text { raspberry pear, etc. }\end{array}$ & $\begin{array}{l}\text { Lack of this vitamin in the diet leads to the disease pellagra which is } \\
\text { characterized by soreness of tongue, pigmented skin and diarrhea. }\end{array}$ \\
\hline $\begin{array}{l}\text { Vitamin C } \\
\text { (ascorbic acid) }\end{array}$ & $\begin{array}{l}\text { Barbadoscherry, aonla,guava, korukkapalli, } \\
\text { musambi, orange, strawberry, lemon, lime, } \\
\text { zizyphus, grape, pineapple, pear, etc. }\end{array}$ & $\begin{array}{l}\text { Prevents scurvy, aids wound healing, healthy immune system and car- } \\
\text { diovascular disease. } \\
\text { Deficiency causes weakness, bleeding gums and defective bone growth. }\end{array}$ \\
\hline $\begin{array}{l}\text { Vitamin E } \\
\text { (tocopherols) }\end{array}$ & Papaya, mango, kiwifruit, tomato fruit. & Heart disease, LDL-oxidation, immune system, diabetes, cancer. \\
\hline $\begin{array}{l}\text { Vitamin K } \\
\text { (phylloquinone) }\end{array}$ & Kiwifruit, tomato fruit, grape, pomegranate. & Synthesis of blood procoagulant factors. \\
\hline Fiber & $\begin{array}{l}\text { Aonla, bael, guava, pomegranate, custard } \\
\text { apple, wood apple, grape, mango, etc. }\end{array}$ & $\begin{array}{l}\text { Lack of adequate dietary fiber in diets containing refined foods leads } \\
\text { to constipation and colon cancer. }\end{array}$ \\
\hline Calcium & $\begin{array}{l}\text { Litchi, karonda, currants, wood apple, } \\
\text { fresh dates, phalsa, pilu, pomegranate, } \\
\text { guava, etc. }\end{array}$ & $\begin{array}{l}\text { Osteoporosis, formation and maintenance of skeleton and teeth. It is } \\
\text { required for normal contraction of muscle to make limbs move, heart } \\
\text { for its normal function, nervous activity and blood clotting. }\end{array}$ \\
\hline Iron & $\begin{array}{l}\text { Karonda, fresh date, green mango, cur- } \\
\text { rants, watermelon, grape, pomegranate, } \\
\text { custard apple, bael, etc. }\end{array}$ & $\begin{array}{c}\text { Formation of hemoglobin of red cells of blood and plays an important } \\
\text { role in the transport of oxygen. } \\
\text { Required for tissue oxidation-reduction. }\end{array}$ \\
\hline Magnesium & $\begin{array}{l}\text { Grape, mango, plum, custard apple, } \\
\text { phalsa, pomegranate, etc. }\end{array}$ & $\begin{array}{l}\text { It is required for osteoporosis, nervous system, teeth, immune system } \\
\text { and cellular metabolism. }\end{array}$ \\
\hline Potassium & $\begin{array}{l}\text { Aonla, bael, lime, loquat, phalsa, peaches, } \\
\text { muskmelon, noni, etc. }\end{array}$ & $\begin{array}{l}\text { Hypertension, stroke, arteriosclerosis. Essential to maintain osmotic } \\
\text { balance and keep cells in proper shape. }\end{array}$ \\
\hline Folic acid & $\begin{array}{l}\text { Tomato fruit, pomegranate, bael, lime, } \\
\text { loquat, phalsa, etc. }\end{array}$ & Birth defects, cancer, heart disease, nervous system. \\
\hline Phosphorus & $\begin{array}{l}\text { Currants, raspberry, wood apple, pome- } \\
\text { granate, bael, lime, loquat, phalsa, etc. }\end{array}$ & $\begin{array}{l}\text { Deposited as calcium phosphate in the bone and the teeth. } \\
\text { Phosphorus is also a component of nucleic acids. }\end{array}$ \\
\hline Zinc & $\begin{array}{l}\text { Mango, pomegranate, custard apple, } \\
\text { wood apple, etc. }\end{array}$ & $\begin{array}{l}\text { It is a co-factor for a number of enzymes. } \\
\text { Zinc deficiency leads to growth failure and poor development } \\
\text { of gonadal function. }\end{array}$ \\
\hline Copper & $\begin{array}{l}\text { Mango, citrus, pomegranate, custard } \\
\text { apple, wood apple, grape, etc. }\end{array}$ & $\begin{array}{l}\text { It is involved in iron absorption, cross linking of connective tissues, } \\
\text { neurotransmission and lipid metabolism. }\end{array}$ \\
\hline
\end{tabular}




\subsection{Flavonoids and polyphenols}

Flavonoids and polyphenols are the most important constituents of different fruit juices that have the ability to increase their antioxidant potential [61], affect lipid metabolism [62], and cholesterol absorption [63]. Polyphenols are mostly derivatives, and/or isomers of flavones, isoflavones, flavonols, catechins, lignins, tannins and phenolic acids [36]. Dietary polyphenols may offer indirect protection by activating endogenous defense systems and by modulating cellular signaling processes such as NF-кB activation, AP-1 DNA binding, glutathione biosynthesis, PI3-kinase/Akt pathway, MAPK proteins (ERK, JNK and P38) activation, and the translocation into the nucleus of Nrf2 [64]. They also contain phenolic constituents such as chlorogenic, arbutin, caffeic, $p$-coumaroyl quinic and $p$-coumaric acids, and a number of procyanidins and flavonol glycosides [65, 66].

Apple and cloudy apple juice contains quercetin, chlorogenic and other phenolic acids as well as dihydrochalcones like phloridzin and phloretin xyloglucoside [67], that can reduce some forms of cancer [68]. Berries (cranberry, blackberry, raspberry and strawberry) are rich in anthocyanins (cyanidin, pelargonidin), flavonoids (kaempferol and quercetin derivatives), ellagitannins and proanthocyanidins $[69,70]$. Black raspberry juice has demonstrated high antioxidant capacity, which has been attributed to its high concentration of total anthocyanins and total phenolic compounds [71].

The main flavonoids found in citrus juice are limonoids, hesperidine, narirutin, naringin, flavanones, flavones, flavonols and eriocitrin $[72,73]$ and carotenoids such as $\beta$-carotene, $\alpha$-carotene, $\beta$-cryptoxanthin, lutein, zeaxanthin, lycopene and limonoids $[23,74]$. Guava fruit juice is very nutritious in respect of having ascorbic acid, pectin and antioxidants along with high amounts of flavonoids and polyphenols that serve as natural laxatives and protect the colon from carcinogenesis [11]. Grape juice is well known for the presence of resveratrol, flavonoids and anthocyanins [75-77]. They thus have beneficial effects on markers of coronary heart disease [78, 79] and exhibit many biologically significant functions, such as protection of body tissues against oxidative stress, and degenerative diseases like cancer and cardiovascular disease [61]. Red wine is a type of fermented grape juice having different types of phenolic acids like gallic acid, coumaric acid, caffeic acid and derivatives such as chlorogenic acid and flavonoids which are not essential for survival but over the long term may provide protection against a number of chronic diseases [77].

Fresh mango juice is a source of lupeol, a potential anti-carcinogenic compound against pancreatic and prostate cancers besides several other benefits in cardiovascular health, reducing risk of kidney stone formation and even reducing the rate of ageing [80]. Bael fruit juice is a very good source of marmelosin which is an age-old known remedy for dysentery, diabetes and psoralene for skin infections, and also as a heart tonic [80]. Pomegranate juice is rich in phenolic anthocyanins such as delfinidin, cyanidine, pelargonidine [81], and ellagitannins (92\%) such as ellagic acid, punicalagin and punicaline [82] which help in reducing blood pressure by inhibiting ACE (angiotensin converting enzyme-1) enzyme activity, reversing damage to vessels [83], preventing prostate cancer [84], colon cancer [85] and arthritis [86], protecting phagocyte cells against auto-oxidative damage through $\beta$-carotene, maintaining blood glucose levels in the normal range [83, 87], stimulating T-cell functions, supporting formation of cytokines, and increasing the capacity of cells which naturally inhibit tumors [88]

The polysaccharide and phytochemicalrich fruit juice of Morinda citrifolia (noni) is used to treat hypertension, diabetes mellitus, bronchial asthma, rheumatoid arthritis, some cancers, and sexual dysfunction [89]. Tomato juice is a major source of lycopene [90] and is used to treat cancer particularly of the prostate [91], heart disease and male infertility. Cranberry juice reduces the incidence of urinary tract infections in women [92].

Much research suggests that polyphenols with other nutrients found in fruit juice help to slow the ageing process and reduce the risk of many diseases including cancer, heart 
disease, stroke, high blood pressure, cataracts, urinary tract infections [93], and Alzheimer's disease [94, 95]. The intake of polyphenols in the diet should be about $1 \mathrm{~g}$ per day [96]. We synthesized the different bioactive compounds present in fruit juices (table III).

\subsection{Antioxidants}

Recently, there has been much interest in the natural sources of antioxidant phytochemicals of plant origin, especially fruits juices [61]. The antioxidant profile of fruit juices is complex and includes carotenoids (e.g., lycopene, $\beta$-carotene), tocopherols and ascorbic acid, as well as polyphenols [97]. Vitamin C acts as a powerful antioxidant by protecting the body from oxidative stress and helps to build and repair body cells [23], along with immunity from infections and diseases. Vitamin $\mathrm{C}$ has been shown to reduce the levels of C-reactive protein, a marker of inflammation and provide protection against immune system malfunctioning, infection, cancer, harmful side effects of pollutants, and cardiovascular disease risk in humans $[98,99]$.

Consumption of fruit juices, such as cranberry, pomegranate, tomato and orange

\begin{tabular}{|c|c|c|c|}
\hline Constituent & Compound & Sources & Effect on human wellness \\
\hline \multicolumn{4}{|l|}{ Phenolic compounds } \\
\hline Proanthocyanins & Tannin, ellagic acid, ferulic acid & $\begin{array}{l}\text { Apple, grape, cranberry, } \\
\text { pomegranate, grapefruit }\end{array}$ & Cancer \\
\hline Anthocyanidins & $\begin{array}{l}\text { Cyaniding, malvidin, } \\
\text { delphinidin, pelargonidin, } \\
\text { peonidin, petunidin }\end{array}$ & $\begin{array}{l}\text { Apple, black berry, blueberry, } \\
\text { cranberry, grape, peach, plum, } \\
\text { pomegranate, strawberry }\end{array}$ & $\begin{array}{l}\text { Heart disease, cancer initiation, } \\
\text { diabetes, cataracts, blood } \\
\text { pressure, allergies }\end{array}$ \\
\hline Flavan-3-ols & $\begin{array}{l}\text { Epicatechin, epigallocatechin, } \\
\text { catechin, gallocatechin }\end{array}$ & $\begin{array}{l}\text { Apple, blackberries, plums, } \\
\text { raspberries, strawberries }\end{array}$ & Platelet, aggregation, cancer, \\
\hline Flavanones & $\begin{array}{l}\text { Hesperetin, naringenin, } \\
\text { eriodictyol }\end{array}$ & $\begin{array}{c}\text { Orange, grapefruit, lemons, lime, } \\
\text { tangerine, grape }\end{array}$ & Cancer \\
\hline Flavones & Luteolin, apigenin & guava & Cancer, allergies, heart disease \\
\hline Flavonols & $\begin{array}{l}\text { Quercetin, kaempferol, } \\
\text { myricetin, rutin }\end{array}$ & Cranberry & $\begin{array}{l}\text { Heart disease, cancer initiation, } \\
\text { capillary protectant }\end{array}$ \\
\hline Phenolic acids & $\begin{array}{l}\text { Caffeic acid, chlorogenic acid, } \\
\text { coumaric acid, ellagic acid }\end{array}$ & $\begin{array}{l}\text { Blackberry raspberry, strawberry, } \\
\text { apple, peach, plum, cherry }\end{array}$ & Cancer, cholesterol \\
\hline \multicolumn{4}{|l|}{ Carotenoides } \\
\hline Lycopene & - & $\begin{array}{l}\text { Tomato, watermelon, papaya, } \\
\text { brazilian guava, red grapefruit }\end{array}$ & $\begin{array}{l}\text { Cancer, heart disease, male } \\
\text { infertility }\end{array}$ \\
\hline$\alpha$ - carotene & - & Kiwifruit, peaches, mango, papaya & Tumor growth \\
\hline B- carotene & - & Mango, papaya & Cancer \\
\hline Xanthophylls & $\begin{array}{l}\text { Lutein, zeaxanthin, } \\
\text { B-cryptoxanthin }\end{array}$ & Citrus, pomegranate, bael & Muscular degeneration \\
\hline Monoterpenes & Limonene & Orange, citrus, grapefruit, tangerine & Cancer \\
\hline \multicolumn{4}{|l|}{ Sulfur compounds } \\
\hline Sulfur compounds & $\begin{array}{c}\text { Glucosinolates, } \\
\text { isothiocyanates, indoles, allicin, } \\
\text { diallyl isulphide }\end{array}$ & Apple, korukkepalli & $\begin{array}{l}\text { Cancer, cholesterol, blood } \\
\text { pressure, diabetes }\end{array}$ \\
\hline
\end{tabular}


tends to increase plasma levels of antioxidant vitamins [100, 101]. Each antioxidant vitamin has a unique free radical scavenging mechanism [102, 103]. Carotenoids responsible for the orange color of orange and tangerine juice are $\alpha$ - carotene, zetaantheraxanthin (yellowish), violaxanthin (yellowish), $\beta$-citraurin (reddish orange), and $\beta$-cryptoxanthin (orange), the red or pink color of the pigmented grapefruit juice varieties is due to the presence of lycopene [23], and red color in orange juice is due to the presence of anthocyanins. All these compounds act as antioxidants in the human body. Citrus fruit (orange, lemon, lime and grape fruit) juices are an important source of bioactive compounds including antioxidants such as ascorbic acid, phenolic compounds and pectins that are important in human nutrition [104, 105].

Orange juice has over 170 different phytochemicals, including more than 60 flavonoids, many of which have been shown not only to have antioxidant effects but also anti-inflammatory and anti-tumor activity [72]. Pomegranate, aonla, apple, strawberry, bael and custard apple juice have moderate antioxidants with an activity of 12-64 mM FRAP (ferric reducing antioxidant potential). Antioxidants found in fruit juices are measured by ORAC score (Oxygen Radical Absorbance Capacity). The higher the ORAC score (blueberry juice, 2,400; strawberry juice, 1,540; raspberry juice, 1,220; plum juice, 949; orange juice, 750; grapes juice, 739; cherry juice, 670; kiwi fruit juice, 602), the greater its antioxidant capacity [36].

\section{Medicinal properties of fruit juices}

Consuming fruit juices has a natural beneficial effect on the human system by hydrating it and acting as a healthy electrolyte drink [2, 3]. The water absorbed by sick persons in this manner has an added advantage of supplying sugar and minerals at the same time [64]. These juices lower the urine density and thereby accelerate the elimination of nitrogenous wastes and chlorides by acting as a diuretic. Fruit juices have a normalizing effect and give the body a boost of energy so that it can overcome a number of health-related problems [10]. It is effective in curing dehydration, fatigue, constipation and other digestive disturbances, kidney and bladder disorders, and vision problems such as glaucoma and cataract [4]. This amazing fluid can help repair any damage to the digestive tract by relieving stomach pain and normalizing intestinal functions. More recently, the influence of vitamin C from fruit juices in gene modulation and biochemical pathways modification has been shown, particularly in blood vessel endothelium [12] and atherosclerosis [106].

Folate from citrus and pineapple juice is essential for the prevention of spina bifida [107] and premature birth [108]. It also helps in maintaining a low level of the amino acid homocysteine, a marker of inflammation that has been associated with a higher risk of heart disease, stroke, and heart failure [24]. A number of studies have shown that the phytochemicals present in fruit juices inhibit chronic inflammatory diseases like Alzheimer's disease [94, 95], insulin resistance [109, 110], diabetes, cardiovascular disease, osteoporosis, arthritis [111], cognitive functions and brain diseases [112], and some forms of cancer [113]

\subsection{Glycemic index and diabetes}

The worldwide burden of type-2 diabetes has increased rapidly in tandem with the increase in obesity. The number of people with diabetes was 171 million worldwide in 2000 , and this number is projected to increase to at least 366 million by the year 2030 [32]. Fruit juices generally have a low glycemic index (GI) [114] and contain compounds that limit or prevent insulin resistance. Because carbohydrates in lowGI foods break down more slowly than in high GI foods, there is a more gradual rise in blood sugar levels that helps people to manage diabetes and obesity [114]. The glycemic index of a food refers to its effect on blood sugar levels. The number is a comparison with a reference food, in this case the sugar, glucose. The World Health Organization and Food and Agriculture Organization 
(FAO) have recommended that people should base their diets on low GI foods in order to lessen the risk of coronary heart disease, diabetes, and obesity [115].

The GI of some common fruits and unsweetened fruit juices is: for watermelon, 72; pineapple, 46; mango, 55; orange, 52; lime, 45; unsweetened apple juice, 41; apple, 40; pear, 36; peach, 28; grapefruit, 48, and cherry, 32 [114]. A reduction in insulin resistance, oxidative stress and inflammation were reported after ingestion of several fruit juices including grapefruit juice [116], orange juice [117], cranberry juice [19] and blueberry juice [118]. Fruit juices dilate blood vessels improving blood circulation thus reducing clot formation and benefitting diabetics. Fruit juices also contain certain forms of dietary fiber and amino acids that help moderate sugar absorption and improve insulin sensitivity. Daily intake of orange juice may increase the production of somatostatin, an inhibitor of insulin secretion, and help in managing diabetes [119].

\subsection{Cardiovascular health}

Fruit juice keeps the cardiovascular system in good condition and helps in preventing cardiovascular disease [4], particularly atherosclerosis [111]. It acts as a cleanser inside blood vessels, scrubbing away arterial deposits that lead to heart attack and stroke [14, 15]. The principal mechanisms of action of fruit juice may include the following: increased serum antioxidant capacity, decreased plasma lipids and lipid peroxidation, decreased oxidized-LDL uptake by macrophages, decreased intima media thickness, atherosclerotic lesion areas, inflammation, angiotensin converting enzyme activity, systolic blood pressure, and enhanced biological actions of nitric oxide, thereby controlling progression of atherosclerosis and the subsequent development of coronary heart disease and stroke [120].

Fruit juices present a heart-healthy and colorful array of phytochemicals including carotenoids and polyphenols like flavonoids, resveratrol, ellagitannins, isothiocyanates and organosulfur compounds which are associated with lower risks of cardiovascular disease [121]. Fruit juices are good sources of potassium and magnesium which help in reducing high blood pressure [122]. Several fruit juices seem to be able to limit blood clot formation by preventing platelets from agglutinating in the blood vessels [78, 123, 124].

The pectin in fruit juice reduces cholesterol levels which, in turn, decrease cardiovascular risk [125]. Epidemiological studies on dietary citrus flavonoids showed a reduction in risk of coronary heart disease [126]. Fruit juices can increase the level of high density lipoproteins (HDL) and decrease the formation and oxidation of low density lipoproteins (LDL) that are deposited in the blood vessels [127]. It is known that naringin and hesperidin inhibit the first enzyme in the biosynthesis of cholesterol (HMG-Co reductase) [128]. Naringin inhibits the transcription of HMGCo reductase, the activity of microsomal triglyceride transfer protein (MTP) and the transcription of acyl-coenzyme A: cholesterol acyltransferase 2 (ACAT2) the enzyme which in the final phase of LDL production attaches cholesterol to the lipoproteins [129]. Similarly, naringin and anthocyanins from berries have a beneficial effect on lipoprotein profiles by decreasing LDLcholesterol and increasing HDL-cholesterol concentrations [130].

Apple juice polyphenols may act by inhibiting cholesterol ester transfer protein (CETP) [131]. A reduction of plasma cholesterol by citrus juice flavonoids is associated with a modulation of the expression of the LDL receptor (LDLR) gene [132]. The fortification of juices with calcium and phytosterol provides some supplementation for cardiovascular benefits [133].

Pomegranate juice, citrus juice, jamun juice and phalsa juice significantly reduce total cholesterol, low density lipoproteins (LDL), the LDL/HDL ratio, and the ratio of total cholesterol to HDL [134]. Consumption of pomegranate juice may modify heart disease risk factors in patients with hyperlipidemia [135]. When ingested, pomegranate juice could help patients with carotid artery stenosis, decrease carotid intimamedia thickness, and their systolic blood 
pressure [136]. Postprandial hyperlipidemia and oxidative stress, a well-defined risk factor for atherosclerosis, could be reduced by phenolic-rich jamun, phalsa and grape juice. Phenolic compounds of different fruit juices significantly ameliorated plasma lipid levels. After drinking $100 \mathrm{~mL}$ of red grape juice per day for 14 days, the concentration of cholesterol-standardized tocopherol and antioxidant capacity of plasma were significantly increased, and oxidized LDL was significantly reduced [137]. Daily intake of $100 \mathrm{~mL}$ of citrus fruit juice after dinner significantly reduced hyperlipidemia and oxidative stress due to the presence of citric acid, ascorbic acid and different phenolic compounds [11].

\subsection{Bone health}

Calcium plays a vital role in bone health and maintaining bone mineral density. A number of fruit juices are a good source of calcium, e.g., orange juice $(60.3 \mathrm{mg})$, bael juice $(80.2 \mathrm{mg})$, lemon juice $(70.2 \mathrm{mg})$, lime juice $(90.5 \mathrm{mg})$, phalsa juice $(120.0 \mathrm{mg})$, and wood apple juice (130.0 mg) per $100 \mathrm{~mL}$ fruit juice [58]. The phytochemicals present in various fruit juices help in bone mineralization, leading to better bone health and preventing diseases like arthritis [138]. Several fruit juice phytochemicals, mainly polyphenols and carotenoids- $\beta$-cryptoxanthin, $\beta$-carotene and lycopene have a positive influence on bone health by preventing destruction of osteoclasts and arthritis [139]. Citrus juice hesperidin and naringin may act through the bone morphogenetic proteins (BMPs) pathway that induces the formation of bone and cartilage [138, 140]. It should also be mentioned that citrus and pomegranate juice may have a positive effect on arthritis [16, 17].

\subsection{Brain health, cognition and ageing}

Compounds like flavonoids and ascorbic acid present in fruit juices have an interesting role in cognitive development of the brain by increasing its neurological activity manifold. Many research reports have shown that grape juice [141, 142], berries juice [143, 144] and citrus juice [145] play an important role in maintaining cognition, limiting brain ageing, and possibly slowing the progress of Alzheimer's disease [146]. The ability of juice compounds, particularly flavonoids, to cross the barrier protecting the brain (blood brain barrier) underlies the beneficial activity of these compounds [147].

The neuroprotective properties of dietary flavonoids are: promoting cerebral vascular blood flow, signaling neuronal cascades leading to an inhibition of cell death, and promotion neuronal differentiation thus preventing deterioration and improving cognitive performance [148]. Ascorbate from fruit juices is proposed as a neuromodulator of neurotransmitters, thus vitamin $\mathrm{C}$ may have potential therapeutic roles against ischemic stroke, Alzheimer's disease, Parkinson's disease, and Huntington's disease [22].

\subsection{Anti-cancer and anti- inflammatory activities}

Maximum fruit juices (apple, aonla, mango, bael, grapes, citrus, noni, phalsa, jamun and pomegranate) are in fashion due to their abundant nutritional richness of having vitamin $\mathrm{C}$, good color and flavor, and being able to reduce the risk of certain cancers (oral, pharynx, larynx, lung, esophagus, stomach, colon, and rectum) [149]. Fruit juices are actually known for their ability to raise serum antioxidant capacity and even offset the oxidative stress and inflammation normally caused by high-fat and high-sugar meals.

Many fruit juice phytochemicals, polyphenols, carotenoids and limonoids may influence mechanisms relevant for cancer prevention that reduce DNA damage and help repair DNA, thus reducing mutations leading to cancer [12, 13]. These include antimutagenic activity, control of angiogenesis, anti-inflammatory mechanisms and modulation of signal transduction pathways. Anthocyanins from various berry juices [150, 151], grape juice [75], citrus flavonoids [73], limonoids [152] and polyphenols 
in apple juice [153, 154] may also have potential anti-carcinogenic activities.

Phenolics of black grape juice prevent inflammation in hemodialysis patients and red grape juice significantly reduces plasma monocyte chemoattractant protein [32], an inflammatory factor involved with CVD risk, and showed effective power to regulate plasma lipids and oxidative stress [137] Antioxidants and ellagic acid present in pomegranate fruit juice prevent prostate, breast, skin, colon, lung, oral, pancreas, intestine, esophagus, bladder, and leukemia cancers by acting as anti-proliferation (growth inhibition, cell cycle disruption and apoptosis), anti-angiogenesis and antiinflammatory agents [155].

\subsection{Skin health}

It is a well proven fact that fruit juices are excellent sources of vitamins, minerals, trace elements, phytochemicals, a variety of enzymes and indispensable nutrients. These ingredients promote epithelial cell proliferation, prevent skin follicular keratosis, assist removal of skin pigmentation, and have the ability to maintain collagen protein, prevent decomposition of fat and melanin, and prevent skin disease activities [11, 156].

Fruit juice maintains the body's acid-base balance, adjusts the functioning of the sweat glands to reduce endocrine acidic waste preventing skin erosion, making skin white, soft, smooth, delicate, and flexible, and to delay skin ageing [11]. Citrus juices are a rich source of vitamin $\mathrm{C}$ and known to maintain skin collagen [157] and are used as skin tonics against acne [7]. It has a cooling effect and acts as a moisturizing agent, and is therefore used in the preparation of creams, lotions, shampoos and allied products. Fruit juice mixed with selected essential oils makes skin smoother and moisturized, acts as a sun block lotion, and is used in a wide range of beauty products.

A beneficial effect of vitamin $\mathrm{C}$ on skin has been found at the gene expression level $[158,159]$. Fruit juice flavonoids have been shown to improve skin microcirculation [160] and collagen formation [18, 161] and carotenoids improve skin health [162].

\subsection{Anemia}

Anemia prevalence among children under 5 years and women is 69\% and over 55\%, respectively. In addition, $40.4 \%$ of children are underweight, $14.0 \%$ of the population is undernourished, and $8.5 \%$ of children die under the age of 5 years due to hunger and iron deficiency. Iron is essential for the formation of hemoglobin of red cells in blood, and plays an important role in the transport of oxygen. Tissues also require iron for various oxidation-reduction processes and other body reactions. However, if there is shortage of iron in body, this leads to anemia.

Vitamin C-rich fruit juices (orange juice, $64 \mathrm{mg}$; aonla juice, $592 \mathrm{mg}$; lime juice, $65 \mathrm{mg}$; papaya juice, $55 \mathrm{mg}$; zizyphus juice, $76 \mathrm{mg}$ per $100 \mathrm{~mL}$ fruit juice) help in increasing non-heme iron absorption to almost double, and prevent iron deficiency anemia in the body $[11,163]$. Hundred per cent juice of fruits like prune, peach, cantaloupe, dates, spinach, lemon, orange, grapefruit, tangerine, lime, mango, papaya, strawberry, kiwi, and tomato should be consumed daily for adequate supply of iron. In regional meals, the addition of citrus fruit juices increased iron availability markedly [164]. The consumption of iron-fortified orange juice is a good strategy to complement iron intake and control iron deficiency anemia [165]. It was found that the fortified juice drink was effective in reducing the prevalence of anemia and improved iron and zinc status of children [166].

\subsection{Prevention of obesity}

The widespread prevalence of obesity in children and the rapidity of recent increases forecast major problems for future healthcare [167]. On the contrary, it appears that people who consume fruit juice (fat free product) were found to have overall healthier diets than those who do not consume fruit juices, along with intakes of fat, saturated fat, sodium, added sugars and fats [11]. Although 100\% fruit juices are not yet implicated in obesity development like other sweetened beverages, they still contain large amounts of sugar and energy. Recommended quantities of fruit juices may play 
a role in the prevention of obesity [65] because they can add to dietary variety both between and within food groups; they can add palatability to the overall diet and palatability has been shown to be an important predictor of body fat [168]. Fruit juices generally have a low GI; this may help in weight management [65].

A number of research studies have evaluated the relationship between consumption of $100 \%$ fruit juice and bodyweight among children and adolescents and found that there is no systematic association between the two $[169,170]$. There is no significant correlation between weight change and the consumption of $100 \%$ fruit juice and drinks in pre-school children [171]. Studies that have looked specifically at fruit juice consumption and obesity have shown mixed results [171, 172]. In fact, the relation between fruit juice consumption and weight gain is very weak because fruit juice is not energy-dense and average juice consumption per day less than $100-150 \mathrm{~mL}$ represents a contribution of less than $2-3 \%$ to the daily energy intake.

\subsection{Dental health}

Several reports have postulated that fruit juices can affect dental health, promote caries and dissolve enamel by high sugar and acid content. In spite of this, some fruit juices are rich in polyphenols, calcium, phosphorus and other minerals supporting dental health [11]. However, the detrimental effects of juice sugar and acidity can easily be eliminated by proper hygiene. Several studies on dental health have found no measurable association between intakes of $100 \%$ fruit juice with prevalence of tooth loss [173]. Concerns have been raised that the acid and sugar content of fruit juice could have a deleterious effect on dental health [174].

Recent studies have revealed that juice polyphenols have a beneficial effect on dental health [175, 176]. Furthermore, calcium added to juice can also add another beneficial effect [177]. The consumption of fruit juice as part of a balanced diet can be compatible with good dental health because of the following reasons:
- All naturally occurring sugars and fermentable carbohydrates are potentially cariogenic and a diet devoid of these nutrients would of course not be feasible. It is clear that despite the presence of sugars in the diet, dental health can be maintained if such foods are consumed appropriately as part of a healthy diet along with good oral hygiene practices.

- The main factor leading to dental erosion and caries is the frequency of consumption, rather than the absolute amount of sugars and the acidity of the product. The main preventive factor for the development of caries obviously is appropriate oral hygiene.

\subsection{Antimicrobial activity}

Fruit juices from the cashew apple are known to have anti-microbial, anti-inflammatory, astringent, diuretic, hypoglycemic, and other medicinal properties [178]. Morinda citrifolia L (noni) has been used in folk remedies by Polynesians for over 2000 years and is reported to have a broad range of therapeutic effects, including antibacterial, anti-viral, anti-fungal, anti-tumor, analgesic, hypotensive, anti-inflammatory, and immune enhancing effects. Koruk (unripe grape from Vitis vinifera) juice immediately decreased the initial populations of Salmonella typhimurium at 1$3.5 \log \mathrm{cfu} \cdot \mathrm{g}^{-1}$ [179]. Spiced extract and juice has been used for prolonging storage quality of juice and reducing spoilage [25]. The possible reason may be that spiced extracts have anti-bacterial properties which check the oxidation of juice constituents and growth of microorganisms [180].

\section{Potential hazards of fruit juices}

Drinking too much juice can lead to poor nutrition, diarrhea, gas, abdominal pain, bloating, and tooth decay. Children have a preference for fruit drinks as they taste good, packaging has an eye appeal, juices are inexpensive and convenient and hence 
are replacing important food items in the diet. A survey of infant feeding in Asian families in England showed that, at 5 months of age, $75 \%$ of Pakistani and White mothers, $63 \%$ of Indian mothers and $61 \%$ of Bangladeshi mothers were giving fruit juices as a source of non-milk drink [177]. By replacing milk in diet, the number of children meeting recommended daily allowances (RDA) for calcium has drastically reduced to just 50\% and thus it is a great health concern. The calcium in these juices is not biologically equivalent to milk calcium.

High vitamin $\mathrm{C}$ in fruit juices promotes iron absorption but polyphenolic compounds in certain juices inhibit iron absorption. Fruit drinks are a common cause of tooth decay and promote picky feeding [177]. Changes in bowel habits, i.e., abdominal distension, flatulence and diarrhea are frequently observed with fruit drinks [33]. A few studies have shown that intake of fruit juices in huge quantities is associated with short stature, obesity, diabetes mellitus and malnutrition [181] and cause toddler diarrhea [182]. Unpasteurized stored fruit juices can be a source of serious bacterial, fungal and yeast infections [180].

\section{Conclusion}

Fruit juices are excellent sources of water and natural sugar and are important principally for containing vitamins, minerals, phytochemicals, antioxidants, pigments, energy, organic acids, dietary fiber and other food components. Consumed in moderation as part of a balanced diet, fruit juices offer properties which both promote good health and reduce the risk of disease. Nevertheless, studies are still fragmentary and need to be expanded in relation to fruit juice consumption, particularly in the clinical area. It appears that juices are most effective against diseases related to chronic inflammation, cancer, heart and bone diseases, problems related to cognition and ageing, and insulin resistance. In most cases, these fruit juice compounds seem to work by modulating gene activity. Furthermore, to reject fruit juices as inadvisable in the context of obesity and dental health would deny the consumer a perfectly healthy and nutritious food, and be completely contrary to the evidence presented in the scientific community. Thus, fruit juices are an excellent choice of drink when consumed moderately as per recommendations.

\section{References}

[1] Bhardwaj R.L., Pandey S., Juice blends - A way of utilization of underutilized fruits, vegetables, and spices: A review, Crit. Rev. Food Sci. 51 (2011) 563-570.

[2] Landon S., Fruit juice nutrition and health, Food Aust. 59 (2007) 533-538.

[3] Xie D., Zhong H., Mo J., Li Z., Cui T., Yi C., Nutritional and medicinal quality of pear juice: Next hotspot, Food 1 (2007) 41-48.

[4] Ruxton C.H.S., Gardner E.J., Walker D., Can pure fruit and vegetable juice protect against cancer and cardiovascular disease too: $A$ review of the evidence, Int. J. Food Sci. Nutr. 3 (2006) 1-24.

[5] Farid S.M., Enani M.A., Levels of trace elements in commercial fruit juices in Jeddah, Saudi Arabia, Med. J. Islamic World Acad. Sci. 18 (2010) 31-38.

[6] Suaad S.A., Eman A.H.A., Microbial growth and chemical analysis of mineral contents in bottled fruit juices and drinks in Riyadh, Saudi Arabia, Res. J. Microbiol. 3 (2008) 319-325.

[7] Nandal U., Bhardwaj R.L., Role of underutilized fruits in nutritional and economic security of tribals: A review, Crit. Rev. Food Sci. 2012, DOI: 10.1080/10408398.2011.616638.

[8] Bhardwaj R.L., Fruit juice: A novel functional food and its categories, Agrobios Newsl. 11 (2012) 87-88.

[9] Marwat S.K., Khan M.A., Fruit plant species mentioned in the holy Qura'n and ahadith and their ethnomedicinal importance, Am.-Eurasian J. Agric. Environ. Sci. 5 (2009) 284-295.

[10] Nandal U., Meena, R.P., Role of fruit juices in nutritional security: A concept, Agrobios Newsl. 11 (2012) 89-90.

[11] Nandal U., Nutritive value and therapeutic uses of beverages. A handbook of foods and nutritional biochemistry, Agrobios, Jodhpur, India, 2013. 
[12] Wu C.H., Wu C.F., Huang H.W., Jao Y.C., Yen G.C., Naturally occurring flavonoids attenuate high glucose-induced expression of proinflammatory cytokines in human monocytic THP-1 cells, Mol. Nutr. Food Res. 53 (2009) 984-995.

[13] Kyle J.A., Sharp L., Little J., Duthie G.G., McNeill G., Dietary flavonoid intake and colorectal cancer: a case-control study, $\mathrm{Br}$. J. Nutr. 7 (2009) 1-8.

[14] Grassi D., Desideri G., Croce G., Tiberti S., Aggio A., Ferri C., Flavonoids, vascular function and cardiovascular protection, Curr. Pharm. Des. 15 (2009) 1072-1084.

[15] Chong M.F., Macdonald R., Lovegrove J.A., Fruit polyphenols and CVD risk: a review of human intervention studies, Br. J. Nutr. 3 (2010) S28-S39.

[16] Shukla M., Gupta K., Rasheed Z., Khan K.A., Haqqi T.M., Consumption of hydrolysable tannins-rich pomegranate extract suppresses inflammation and joint damage in rheumatoid arthritis, Nutrition 24 (2008) 733-743.

[17] Hadipour-Jahromy M., Mozaffari-Kermani R., Chondroprotective effects of pomegranate juice on monoiodoacetate-induced osteoarthritis of the knee joint of mice, Phytother. Res. 24 (2010) 182-185.

[18] Bae J.Y., Lim S.S., Kim S.J., Choi J.S., Park J., Ju S.M., Han S.J., Kang I.J., Kang Y.H., Bog blueberry anthocyanins alleviate photoaging in ultraviolet-B irradiation-induced human dermal fibroblasts, Mol. Nutr. Food Res. 53 (2009) 726-38.

[19] Wilson T., Meyers S.L., Singh A.P., Limburg P.J., Vorsa N., Favorable glycemic response of type 2 diabetics to low-calorie cranberry juice, J. Food Sci. 73 (2008) 241-245.

[20] Davis R.E., Marshall T.A., Qian F., Warren J.J., Wefel J.S., In vitro protection against dental erosion afforded by commercially available, calcium-fortified 100 percent juices, J. Am. Dent. Assoc. 138 (2007) 15931598.

[21] Vafeiadou K., Vauzour D., Lee H.Y., Rodriguez-Mateos A., Williams R.J., Spencer J.P., The citrus flavanone naringenin inhibits inflammatory signalling in glial cells and protects against neuroinflammatory injury, Arch. Biochem. Biophys. 484 (2009) 100-109.

[22] Harrison F.E., May J.M., Vitamin C function in the brain: vital role of the ascorbate transporter SVCT2, Free Radic. Bio. Med. 46 (2009) 719-730.
[23] Zvaigzne G., Karklina D., Seglina D., Krasnova I., Antioxidants in various citrus fruit juices, Chemine Technol. 3 (2009) 56-61.

[24] Sanchez-Moreno C., Jimenez-Escrig A., Martin A., Stroke: roles of B vitamins, homocysteine and antioxidants, Nutr. Res. Rev. 22 (2009) 49-67.

[25] Bhardwaj R.L., Mukherjee S., Effects of juice blending, processing treatment and KMS addition on physic-chemical and microbiological quality of kinnow juice, Int. J. Curr. Trends Sci. Tech. 3 (2012) 59-69.

[26] Wardlaw G.M., Contemporary Nutrition, $4^{\text {th }}$ Ed., McGraw Hill Co., N.Y., U.S.A., 2000.

[27] Addo M.G., Akanwariwiak W.G., AddoFordjour P., Obiri-Danso K., Microbiological and sensory analysis of imported fruit juices in Kumasi, Ghana, Res. J. Microbiol. 3 (2008) 552-558.

[28] Anon., Baseline survey about utilization and future prospects of fruit juices in Sirohi district of Rajasthan, Krishi Vigyan Kendra, Sirohi, Rajasthan, India, 2012, pp. 13-25.

[29] Fulker M.J., The role of fruit in the diet, J. Environ. Radioact. 52 (2001) 147-157.

[30] Holt E.M., Steffen L.M., Moran A., Basu S., Steinberger J., Ross J.A., Hong C.P., Sinaiko A.R., Fruit and vegetable consumption and its relation to markers of inflammation and oxidative stress in adolescents, J. Am. Diet. Assoc. 109 (2009) 414-421.

[31] Lindstrom M., Hanson B.S., Wirfalt E., Ostergren P., Socioeconomic differences in the consumption of vegetable, fruit and fruit juices, Eur. J. Public Health 11 (2001) 51-59.

[32] Anon., Global Burden of Disease, Diabetes Mellitus, World Health Organization, Geneva, Swiss, 2003, pp.111-115.

[33] Anon., The use and misuse of fruit juice in pediatrics, Comm. Nutr. Pediatr. 107 (2001) 1210-1213.

[34] Gupta H., Gupta P., Fruit drinks: How healthy and safe, Indian Pediatr. 45 (2008) 215-217.

[35] Farooqui T., Farooqui A.A., Aging: an important factor for the pathogenesis of neurodegenerative diseases, Mech. Ageing Dev. 130 (2009) 203-215.

[36] Kour K., Singh N.D., Fruits: A smart choice of antioxidants, Agrobios Newsl. 11 (2012) 76-77.

[37] Pallas M., Casadesus G., Smith M.A., CotoMontes A., Pelegri C., Vilaplana J., Camins A., Resveratrol and neurodegenerative diseases: Activation of SIRT1 as the potential 
pathway towards neuroprotection, Curr. Neurovasc. Res. 6 (2009) 70-81.

[38] Vidavalur R., Otani H., Singal P.K., Maulik N., Significance of wine and resveratrol in cardiovascular diseases: French paradox revisited, Exp. Clin. Cardiol.11 (2006) 217-225.

[39] Fernandez-Mar M.I., Mateos R., GarciaParrilla M.C., Puertas B., Cantos-Villar E., Bioactive compounds in wine: Resveratrol, hydroxytyrosol and melatonin: A review, Food Chem. 130 (2012) 797-813.

[40] Walle T., Hsieh F., DeLegge M.H., High absorbtion but very low bioavailability of oral resveratrol in humans, Drug Metab. Dispos. 32 (2004) 1377-1382.

[41] Vitaglione P., Sforza S., Galaverna G., Ghidini C., Caporaso N., Vescovi P.P., Bioavailability of trans-resveratrol from red wine in humans, Mol. Nutr. Food Res. 49 (2005) 495-504.

[42] Jannin B., Menzel M., Berlot J.P., Delmas D., Lancon A., Latruffe N., Transport of resveratrol, a cancer chemopreventive agent, to cellular targets: Plasmatic protein binding and cell uptake, Biochem. Pharmacol. 68 (2004) 1113-1118.

[43] Martin S., Andriambeloson E., Takeda K., Andriantsitohaina R., Red wine polyphenols increase calcium in bovine aortic endothelial cells: a basis to elucidate signalling pathways leading to nitric oxide production, $\mathrm{Br}$. J. Pharmacol. 135 (2002) 1579-1587.

[44] Ndiaye M., Chataigneau M., Lobysheva I., Chataigneau T., Schini- Kerth V.B., Red wine polyphenol-induced, endothelium-dependent NO mediated relaxation is due to the redox-sensitive PI3-kinase/Akt-dependent phosphorylation of endothelial NO synthase in the isolated porcine coronary artery, Faseb J. 19 (2005) 455-457.

[45] Dasgupta B., Milbrandt J., Resveratrol stimulates AMP kinase activity in neurons, Proc. Natl. Acad. Sci. U.S.A. 104 (2007) 72177222.

[46] Calabrese V., Cornelius C., Mancuso C., Barone E., Calafato S., Bates T., Rizzarelli E., Kostova A.T., Vitagenes, dietary antioxidants and neuroprotection in neurodegenerative diseases, Front Biosci. 14 (2009) 376-397.

[47] Fuenzalida K., Quintanilla R., Ramos P., Piderit D., Fuentealba R.A., Martinez G., Inestrosa N.C., Bronfman M., Peroxisome proliferator-activated receptor gamma upregulates the $\mathrm{Bcl}-2$ anti-apoptotic protein in neurons and induces mitochondrial stabilization and protection against oxidative stress and apoptosis, J. Biol. Chem. 282 (2007) 37006-37015.

[48] Sundararajan S., Gamboa J.L., Victor N.A., Wanderi E.W., Lust W.D., Landreth G.E., Peroxisome proliferator-activated receptorgamma ligands reduce inflammation and infarction size in transient focal ischemia, Neuroscience 130 (2005) 685-696.

[49] Rubiolo J.A., Mithieux G., Vega F.V., Resveratrol protects primary rat hepatocytes against oxidative stress damage: activation of the Nrf2 transcription factor and augmented activities of antioxidant enzymes, Eur. J. Pharmacol. 591 (2008) 66-72.

[50] Tang B.L., Chua C.E., SIRT1 and neuronal diseases, Mol. Asp. Med. 29 (2008) 187-200.

[51] Marambaud P., Zhao H., Davies P., Resveratrol promotes clearance of Alzheimers disease amyloid-beta peptides, J. Biol. Chem. 280 (2005) 37377-37382.

[52] Kim Y.A., Lim S.Y., Rhee S.H., Park K.Y., Kim C.H., Choi B.T., Lee S.J., Park Y.M., Choi Y.H., Resveratrol inhibits inducible nitric oxide synthase and cyclooxygenase-2 expression in betaamyloid-treated C6 glioma cells, Int. J. Mol. Med. 17 (2006) 10691075.

[53] Wang Q., Sun A.Y., Simonyi A., Miller D.K., Smith R.E., Luchtefeld R.G., Korthuis R.J., Sun G.Y., Oral administration of grape polyphenol extract ameliorates cerebral ischemia/reperfusion induced neuronal damage and behavioral deficits in gerbils: comparison of pre- and post-ischemic administration, J. Nutr. Biochem. 20 (2009) 369-377.

[54] Anekonda T.S., Resveratrol a boon for treating Alzheimers disease, Brain Res. Rev. 52 (2006) 316-326.

[55] Mancuso C., Bates T.E., Butterfield D.A., Calafato S., Cornelius C., De Lorenzo A., Dinkova Kostova A.T., Calabrese V., Natural antioxidants in Alzheimers disease, Expert Opin. Inv. Drug 16 (2007) 1921-1931.

[56] De la Lastra C.A., Villegas I., Resveratrol as an antioxidant and pro-oxidant agent: mechanisms and clinical implications, Biochem. Soc. T. 35 (2007) 1156-1160.

[57] Dillon A., Fruit juice profiles, in: Nagy S., Wade R.L. (Eds.), Methods to detect adulteration of fruit juice beverages, AGscience, Auburndale, U.S.A., Append. II, 1995, 359433.

[58] Gopalan C., Ramashastri B.V., Balasubramanian S.C., Rao N.B.S., Deosthale Y.G., 
Pant, K.C., Nutritive value of Indian foods, NtI. Inst. Nutr., ICMR, Hyderabad, India, 2010.

[59] Wills R.B.H., Composition of Australian fresh fruits and vegetables, Food Technol. Aust. 39 (1987) 523-530.

[60] Somogy L.P., Ramaswamy H.S., Hui Y.H., Processing fruits: science and technology, Vol. 2, Major processed products, Technomics Publ. Co., Inc., Lancaster, U.S.A., 1996.

[61] Tsai H.L., Chang S.K.C., Chang S.J., Antioxidant content and free radical scavenging ability of fresh red pummel [Citrus grandis (L.) Osbeck] juice and freeze-dried products, J. Agr. Food Chem. 55 (2007) 2867-2872.

[62] Akazone Y., Characteristic and physiological functions of polyphenols from apple, Biofactors 22 (2004) 311-314.

[63] Aprikian O., Levrat-Verny M.A., Besson C., Busserolles J., Remesy C., Demigne C., Apple favourably affects parameters of cholesterol metabolism and of anti-oxidative protection in cholesterol feed rats, Food Chem. 75 (2001) 445-452.

[64] Anon., Fruit juice nutrition and health, Int. Fed. Fruit Juice Prod., IFU Sci. Rev. 2011, pp. 11.

[65] Ma Y., Association between dietary carbohydrates and body weight, Am. J. Epidemiol. 161 (2005) 359-367.

[66] Tanrioven D., Eksi A., Phenolic compound in pear juice from different cultivars, Food Chem. 93 (2005) 89-93.

[67] Soler C., Soriano J.M., Manes J., Appleproducts phytochemicals and processing: a review, Nat. Prod. Commun. 4 (2009) 659670.

[68] Barth S.W., Fahndrich C., Bub A., Dietrich H., Watzl B., Will F., Briviba K., Rechkemmer, G., Cloudy apple juice decreases DNA damage, hyperproliferation and aberrant crypt foci development in the distal colon of $\mathrm{DMH}$ initiated rats, Carcinogenesis 26 (2005) 1414-1421.

[69] Szajdek A., Borowska E.J., Bioactive compounds and health-promoting properties of berry fruits: a review, Plant Food Hum. Nutr. 63 (2008) 147-156.

[70] Seeram N.P., Berry fruits: compositional elements, biochemical activities, and the impact of their intake on human health, performance, and disease, J. Agr. Food Chem. 56 (2008) 627-629.
[71] Wang S.Y., Lin H.S., Antioxidant activity in fruits and leaves of blackberry, raspberry, and strawberry varies with cultivar and developmental stage, J. Agr. Food Chem. 48 (2000) 140-146.

[72] Baghurst K., The health benefits of citrus fruits, CSIRO, Health Sciences and Nutrition, Hortic. Aust. Ltd. Sidney, Aust., 2003, 128 p.

[73] Benavente-Garcia O., Castillo J., Update on uses and properties of citrus flavonoids: new findings in anticancer, cardiovascular, and anti-inflammatory activity, J. Agr. Food Chem. 56 (2008) 6185-6205.

[74] Marti N., Mena P., Cánovas J.A., Micol V., Saura D., Vitamin $C$ and the role of citrus juices as functional food, Nat. Prod. Commun. 4 (2009) 677-700.

[75] Iriti M., Faoro F., Bioactivity of grape chemicals for human health, Nat. Prod. Commun. 4 (2009) 611-634.

[76] Marques F.Z., Markus M.A., Morris B.J., Resveratrol: Cellular actions of a potent natural chemical that confers a diversity of health benefits, Int. J. Biochem. Cell Biol. 41 (2009) 2125-2128.

[77] Pezzuto J.M., Venkatasubramanian V., Hamad M., Morris K.R., Unravelling the relationship between grapes and health, J. Nutr. 139 (2009) 1783S-1787S.

[78] Freedman J.E., Parker C., Li L., Perlman J.A., Frei B., Ivanov V., Deak L.R., lafrati M.D., Folts J.D., Select flavonoids and whole juice from purple grapes inhibit platelet function and enhance nitric oxide release, Circulation 103 (2001) 2792-2798.

[79] Folts J.D., Potential health benefits from the flavonoids in grape products on vascular disease, Adv. Exp. Med. Biol. 505 (2002) 95-111.

[80] Sen N.L., Underutilised horticulture crops: Trends, challenge and opportunities in the 21st century, in: Proc. Winter school on "Exploitation of underutilized horticultural crops" at MPUAT, Udaipur, India, 2003, pp. 224-231.

[81] Mazza G., Miniati E., Anthocyanins in fruits, vegetables and grains, CRC Press, Lond., U.K., 1993, 362 p.

[82] Lansky E.P., Newman R.A., Punica granatum (pomegranate) and its potential for prevention of inflammation and cancer, J. Ethnopharmacol. 107 (2007) 177-206.

[83] Aviram M., Rosenblat M., Volkova N., Coleman R., Pomegranate by product administration to apolipoprotein e-definicient 
mice attenuates atherosclerosis development as a result of decreased macrophage oxidative stress and reduced cellular uptake of oxidized low-density lipoprotein, J. Agr. Food Chem. 54 (2006) 1928-1935.

[84] Malik A., Afaq F., Sarfaraz S.M., Adhami V. Syed D., Mukhtar H., Pomegranate fruit juice for chemoprevention and chemotherapy of prostate cancer, Univ. Wisconsin, Dep. Dermatol., Madison, U.S.A., 2005, 451 p.

[85] Khan S.A., The role of pomegranate (Punica granatum L.) in colon cancer, Pak. J. Pharm. Sci. 22 (2009) 346-348.

[86] Okamoto L.M., Hamamoto Y.O., Yamato H., Yoshiruma $\mathrm{H}$., Pomegranate extract improves a depressive state and bone properties in menopausal syndrome model ovariectomized mice, J. Ethnopharmacol. 92 (2004) 93-101.

[87] Lansky E.P., Schubert S., Newman I. Pharmacological and therapeutic properties of pomegranate, 1st Symp. on the Pomegranate, Orihuela, Spain, 1998.

[88] Basu A., Penugonda K., Pomegranate juice: a heart-healthy fruit juice, Nutr. Rev. 67 (2009) 49-56.

[89] Hirazumi H., Furusawa E., An immunomodulatory polysaccharide-rich substance from the fruit juice of Morinda citrifolia (noni) with anti-tumor activity, Phytother. Res. 13 (1999) 380-387.

[90] Lee C.Y., Isaac H.B., Huang S.H., Long L.H., Wang H., Gruber J., Ong C.N., Kelly R.P., Halliwell B., Limited antioxidant effect after consumption of a single dose of tomato sauce by young males, despite a rise in plasma lycopene, Free Radic. Res. 43 (2009) 622-628.

[91] Campbell J.K., Tomato phytochemicals and prostate cancer risk, Am. Soc. Nutr. Sci. 11 (2004) 3486S-3492S.

[92] Jepson R.G., Mihaljevic L, Craig J., Cranberries for preventing urinary tract infections, Cochrane Database Syst. Rev. (2) (2004) CD001321.

[93] Chan A., Apple juice concentrate maintains acetylcholine levels following dietary compromise, J. Alzheimers Dis. 9 (2006) 287-291.

[94] Granic I., Dolga A.M., Nijholt I.M., Van Dijk G., Eisel U.L., Inflammation NF-kappaB in Alzheimers disease and diabetes, J. Alzheimers Dis. 16 (2009) 809-821.
[95] Kanapuru B., Ershler W.B., Inflammation, coagulation, and the pathway to frailty, Am. J. Med. 122 (2009) 605-613.

[96] Scalbert A., Williamson G., Dietary intake and bioavailability of polyphenols, J. Nutr. 130 (2000) 2073S-2085S.

[97] Lugasi A., Hovari J., Antioxidant properties of commercial alcoholic and non-alcoholic beverages, Nahrung 47 (2003) 79-86.

[98] Macias-Matos C., Rodriguez-Ojea A., Chi N., Biochemical evidence of thiamin depletion during the Cuban neuropathy epidemic, 1992-1993, Am. J. Clin. Nutr. 64 (1996) 347-353.

[99] Cadet J.L., Brannock C., Invited reviews free radicals and the pathobiology of brain dopamine systems, Neurochem. Int. 32 (1997) 117-131.

[100] Samman S., Sivarajah G., Masn J.C., Ahmad Z.I., Petocz P., Caterson I.D., A mixed fruit and vegetable concentrate increases plasma antioxidant vitamins and folate and lowers plasma homocysteine in men, J. Nutr. 133 (2003) 2188-2193.

[101]Kiefer I., Prock P., Lawrence C., Wise J., Bieger W., Bayer P., Rathmanner T., Kunze M., Rieder A., Supplementation with mixed fruit and vegetable juice concentrates increased serum antioxidants and folate in healthy adults, J. Am. Coll. Health 23 (2004) 205-211.

[102] Proteggente A.R., Saija A., De Pasquale A., Rice-Evans C.A., The compositional characterisation and antioxidant activity of fresh juices from Sicilian sweet orange (Citrus sinensis L. Osbeck) varieties, Free Radic. Res. 37 (2003) 681-687.

[103] Ghasemi K., Ghasemi Y., Ebrahimzadeh M.A., Antioxidant activity, phenol and flavonoid contents of 13 citrus species peels and tissues, Pak. J. Pharm. Sci. 3 (2009) 277-281.

[104]Fernandez-Lopez J., Zhi N., AlesonCarbonell L., Perez-Alvarez J.A., Kuri V., Antioxidant and antibacterial activities of natural extracts: application in beef meatballs, Meat Sci. 69 (2005) 371-380.

[105] Jayaprakasha G.K., Patil B.S., In vitro evaluation of the antioxidant activities in fruit extracts from citron and blood orange, Food Chem. 101 (2007) 410-418.

[106]Frikke-Schmidt H., Lykkesfeldt J., Role of marginal vitamin $C$ deficiency in atherogenesis: in vivo models and clinical studies, Basic Clin. Pharmacol. 104 (2009) 419-433. 
[107]Bell K.N., Oakley G.P.Jr., Update on prevention of folic acid-preventable spina bifida and anencephaly, Birth Defects Res. A Clin. Mol. Teratol. 85 (2009) 102-107.

[108] Bukowski R., Malone F.D., Porter F.T, Nyberg D.A., Comstock C.H., Hankins G.D., Eddleman K., Gross S.J., Dugoff L., Craigo S.D., Timor-Tritsch I.E., CarrS.R., Wolfe H.M., Dalton M.E., Preconceptional folate supplementation and the risk of spontaneous preterm birth: a cohort study, PLoS Med. 13 (2009) 117-120.

[109]Bluher M., The inflammatory process of adipose tissue, Pediatr. Endocrinol. Rev. 6 (2008) 24-31.

[110] King G.L., The role of inflammatory cytokines in diabetes and its complications, J. Periodontol. 79 (2008) Suppl. 1527-1534.

[111]Bucova M., Bernadic M., Buckingham T., Creactive protein, cytokines and inflammation in cardiovascular diseases, Bratisl Lek Listy 109 (2008) 333-340.

[112] Warnberg J., Gomez-Martinez S., Romeo J., Diaz L.E., Marcos A., Nutrition, inflammation, and cognitive function, Ann. N.Y. Acad Sci. 1153 (2009) 164-175.

[113] Gonda T.A., Tu S., Wang T.C., Chronic inflammation, the tumor microenvironment and carcinogenesis, Cell Cycle 8 (2009) 2005-2013.

[114] Brand-Miller J., Low-glycemic Index diets in the management of diabetes. A metaanalysis of randomised controlled trials, Diabetes Care 26 (2003) 2261- 2267.

[115] Mendosa R., New international table of Glycemic Index (Gl) and Glycemic Load Values, Am. J. Clin. Nutr. 77 (2003) 994-998.

[116]Yao F., Shu G., Yang Y., Shi B., Grapefruit and diet of the type 2 diabetes, Diabetes 53 (2004) A591- A592.

[117]Ghanim H., Mohanty P., Pathak R., Chaudhuri A., Sia C.L., Dandona P., Orange juice or fructose intake does not induce oxidative and inflammatory response, Diabetes Care 30 (2007) 1406-1411.

[118]DeFuria J., Bennett G., Strissel K.J., Perfield J.W., Milbury P.E., Greenberg A.S., Obin, M.S., Dietary blueberry attenuates wholebody insulin resistance in high fat-fed mice by reducing adipocyte death and its inflammatory sequelae, J. Nutr. 139 (2009) 1510-1516.

[119]Alcada M.N., Monteiro R., Calhau C., Azevedo I., Orange juice vs. soft drinks, Arch. Intern. Med. 169 (2009) 315-320.
[120]Joshipura K.J., Hu F.B., Manson J.E., Stampfer M.J., Rimm E.B., Speizer F.E., Colditz G., Ascheiro A., Rosner B., Spiegelman D., Willett W.C., The effect of fruit and vegetable intake on risk for coronary heart disease, Ann. Intern. Med. 134 (2001) 1106-1114.

[121] Erlund I., Koli R., Alfthan G., Favorable effects of berry consumption on platelet function, blood pressure, and HDL cholesterol, Am. J. Clin. Nutr. 87 (2008) 323-331.

[122] Duthie S.J., Jenkinson A.M., Crozier A., Mullen W., Pirie L., Kyle J., Yap L.S., Christen P., Duthie G.G., The effects of cranberry juice consumption on antioxidant status and biomarkers relating to heart disease and cancer in healthy human volunteers, Eur. J. Nutr. 45 (2006) 113-122.

[123] Leifert W.R., Abeywardena M.Y., Cardioprotective actions of grape polyphenols, Nutr. Res. 28 (2008) 729-737.

[124] Mattiello T., Trifiro E., Jotti G.S., Pulcinelli F.M., Effects of pomegranate juice and extract polyphenols on platelet function, J. Med. Food 12 (2009) 334-339.

[125] Bazzano L.A., Joshipura K.J., Li T.Y., Hu F.B., Intake of fruit, vegetables, and fruit juices and risk of diabetes in women, Diabetes Care 31 (2008) 1311-1317.

[126]Di Majo D., Giammanco M., La Guardia M., Tripoli E., Giammanco S., Finotti E., Flavanones in citrus fruit: Structura-antioxidant activity relationships, Food Res. Int. 38 (2005) 1161-1166.

[127] Gorinstein S., Caspi A., Libman I., Lerner H.T., Huang D., Leontowicz H., Leontowicz M., Tashma Z., Katrich E., Feng S., Trakhtenberg S., Red grapefruit positively influences serum triglyceride level in patients suffering from coronary atherosclerosis: studies in vitro and in humans, J. Agr. Food Chem. 54 (2006) 1887-1892.

[128] Nahmias Y., Goldwasser J., Casali M., van Poll D., Wakita T., Chung R.T., Yarmush M.L., Apolipoprotein B-dependent hepatitis C virus secretion is inhibited by the grapefruit flavonoid naringenin, Hepatology 47 (2008) 1437-1445.

[129] Qin Y., Xia M., Ma J., Hao Y., Liu J., Mou H., Cao L., Ling W., Anthocyanin supplementation improves serum LDL and HDL cholesterol concentrations associated with the inhibition of cholesteryl ester transfer protein in dyslipidemic subjects, Am. J. Clin. Nutr. 90 (2009) 485-492. 
[130] Mulvihill E.E., Allister E.M., Sutherland B.G. Telford D.E., Sawyez C.G., Edwards J.Y., Markle J.M., Hegele R.A., Huff M.W., Naringenin prevents dyslipidemia, apolipoprotein $\mathrm{B}$ overproduction and hyperinsulinemia in LDL receptor-null mice with diet-induced insulin resistance, Diabetes 58 (2009) 2198-2210.

[131]Lam C.K., Zhang Z., Yu H., Tsang S.Y., Huang Y., Chen Z.Y., Apple polyphenols inhibit plasma CETP activity and reduce the ratio of non-HDL to HDL cholesterol, Mol. Nutr. Food Res. 52 (2008) 950-958.

[132] Morin B., Nichols L.A., Zalasky K.M., Davis J.W., Manthey J.A., Holland L.J., The citrus flavonoids hesperetin and nobiletin differentially regulate low density lipoprotein receptor gene transcription in HepG2 liver cells, J. Nutr. 138 (2008) 1274-1281.

[133]Devaraj S., Jialal I., Vega-Lopez S., Plant sterol-fortified orange juice effectively lowers cholesterol levels in mildly hypercholesterolemic healthy individuals, Arterioscl. Throm. Vas. 24 (2004) 25-28.

[134] Esmaillzadeh A., Tahbaz F., Gaieni I., AlaviMajd H., Azadbakht L., Cholesterol-lowering effect of concentrated pomegranate juice consumption in type II diabetic patients with hyperlipidemia, Int. J. Vit. Nutr. Res. 76 (2006) 147-150.

[135] Sumner M.D., Elliott-Eller M., Weidner G., Daubenmier J.J., Chew M.H., Marlin R., Raisin C.J., Ornish D., Effects of pomegranate juice consumption on myocardial perfusion in patients with coronary heart disease, Am. J. Cardiol. 96 (2005) 810-813.

[136] Aviram M., Dornfeld L., Pomegranate juice consumption inhibits serum angiotensin converting enzyme activity and reduces systolic blood pressure, Atherosclerosis 158 (2001) 195-197.

[137] Castilla P., Echarri R., Davalos A., Cerrato F., Ortega H., Teruel J.L., Lucas M. F., GomezCoronado D., Ortuno J., Lasuncion M.A., Concentrated red grape juice exerts antioxidant, hypolipidemic, and anti-inflammatory effects in both hemodialysis patients and healthy subjects, Am. J. Clin. Nutr. 84 (2006) 252-262.

[138] Trzeciakiewicz A., Habauzit V., Mercier S., Lebecque P., Davicco M.J., Coxam V., Demigne C., Horcajada M.N., Hesperetin stimulates differentiation of primary rat osteoblasts involving the BMP signalling pathway, J. Nutr. Biochem. 21 (2010) 424-431.

[139] Sahni S., Hannan M.T., Blumberg J., Cupples L.A., Kiel D.P., Tucker K.L., Protective effect of total carotenoid and lycopene intake on the risk of hip fracture: a 17-year follow-up from the Framingham Osteoporosis Study, J. Bone Miner. Res. 24 (2009) 1086-1094.

[140] Horcajada M.N., Habauzit V., Trzeciakiewicz A., Morand C., Gil-Izquierdo A., Mardon J., Lebecque P., Davicco M.J., Chee W.S., Coxam V., Offord E., Hesperidin inhibits ovariectomized-induced osteopenia and shows differential effects on bone mass and strength in young and adult intact rats, J. Appl. Physiol. 104 (2008) 648-654.

[141]Joseph J.A., Shukitt-Hale B., Willis L.M., Grape juice berries, and walnuts affect brain aging and behavior, J. Nutr. 139 (2009) 1813S-1817S.

[142] Wang J., Ho L., Zhao W., Ono K., Rosensweig C., Chen L., Humala N., Teplow D.B., Pasinetti G.M., Grape-derived polyphenolics prevent Abeta oligomerization and attenuate cognitive deterioration in a mouse model of Alzheimers disease, J. Neurosci. 28 (2008) 6388-8892.

[143] Shukitt-Hale B., Cheng V., Joseph J.A., Effects of blackberries on motor and cognitive function in aged rats, Nutr. Neurosci. 12 (2009) 135-140.

[144]Willis L.M., Shukitt-Hale B., Joseph J.A., Recent advances in berry supplementation and age-related cognitive decline, Curr. Opin. Clin. Nutr. 12 (2009) 91-94.

[145] Datla K.P., Christidou M., Widmer W.W., Rooprai H.K., Dexter D.T., Tissue distribution and neuroprotective effects of citrus flavonoid tangeretin in a rat model of Parkinsons disease, Neuroreport 12 (2001) 3871-3875.

[146] Dai Q., Borenstein A.R., Wu Y., Jackson J.C., Larson E.B., Fruit and vegetable juices and Alzheimers: the Kame Project, Am. J. Med. 119 (2006) 751-759.

[147] Youdim K.A., Dobbie M.S., Kuhnle G., Proteggente A.R., Abbott N.J., Rice-Evans C., Interaction between flavonoids and the blood-brain barrier: in vitro studies, $\mathrm{J}$. Neurochem. 85 (2003) 180-192.

[148] Spencer J.P., The impact of fruit flavonoids on memory and cognition, Br. J. Nutr. 104 (2010) S40-S47.

[149] Honda T., Kai I., Ohi G., Fat and dietary fiber intake and colon cancer mortality: a chronological comparison between Japan and United States, Nutr. Cancer 33 (1999) 95-99.

[150] Thomasset S., Berry D.P., Cai H., West K., Marczylo T.H., Marsden D., Brown K., Dennison A., Garcea G., Miller A., Hemingway D., Steward W.P., Gescher A.J., 
Pilot study of oral anthocyanins for colorectal cancer chemoprevention, Cancer Prev. Res. 2 (2009) 625-633.

[151] Matsunaga N., Tsuruma K., Shimazawa M., Yokota S., Hara H., Inhibitory actions of bilberry anthocyanidins on angiogenesis, Phytother. Res. 24 Suppl 1 (2010) S42-47.

[152] Poulose S.M., Harris E.D., Patil B.S., Antiproliferative effects of citrus limonoids against human neuroblastoma and colonic adenocarcinoma cells, Nutr. Cancer 56 (2006) 103-112.

[153] Gerhaeuser C., Cancer chemopreventive potential of apples, apple juice, and apple components, Planta Med. 74 (2008) 16081624.

[154] Veeriah S., Miene C., Habermann N., Hofmann T., Klenow S., Sauer J., Böhmer F., Wölfl, S., Pool-Zobel B.L., Apple polyphenols modulate expression of selected genes related to toxicological defence and stress response in human colon adenoma cells, Int. J. Cancer 122 (2008) 2647-2655.

[155]Amin A.R.M.R., Kucuk O., Khuri F.R., Shin D.M., Perspectives for cancer prevention with natural compounds, J. Clin. Oncol. 27 (2009) 2712-2719.

[156] Cosgrove M.C., Franco O.H., Granger S.P, Murray P.G., Mayes A.E., Dietary nutrient intakes and skin-aging appearance among middle-aged American women, Am. J. Clin. Nutr. 86 (2007) 1225-1231.

[157] Sheetz E., Goldsmith L.A., Nutritional influences on the skin, in: Goldsmith L.A. (Ed.), Physiology, biochemistry, and molecular biology of the skin, Oxford Univ. Press, N.Y., U.S.A., 1991, pp. 1315-1328.

[158] Arai K.Y., Sato Y., Kondo Y., Kudo C., Tsuchiya H., Nomura Y., Ishigami A., Nishiyama T., Effects of vitamin $C$ deficiency on the skin of the senescence marker protein30 (SMP30) knockout mouse, Biochem. Biophys. Res. Commun. 385 (2009) 478-483.

[159] Duarte T.L., Cooke M.S., Jones G.D., Gene expression profiling reveals new protective roles for vitamin $C$ in human skin cells, Free Radic. Bio. Med. 46 (2009) 78-87.

[160] Neukam K., Stahl W., Tronnier H., Sies H., Heinrich U., Consumption of flavanol-rich cocoa acutely increases microcirculation in human skin, Eur. J. Nutr. 46 (2007) 53-56.

[161] Stipcevic T., Piljac J., Vanden Berghe D., Effect of different flavonoids on collagen synthesis in human fibroblasts, Plant Food Hum. Nutr. 61 (2006) 29-34.
[162] Stahl W., Sies H., Carotenoids and flavonoids contribute to nutritional protection against skin damage from sunlight, Mol. Biotechnol. 37 (2007) 26-30.

[163] Hollman P.C., Hertlog M.G., Kalan M.B., Role of dietary flavonoids in protection against cancer and coronary heart disease, Biochem. Soc. Trans. 24 (1996) 785-789.

[164] Chaudhary P., Vir S., Prevention and strategies for control of iron deficiency anaemia, in: Sachdev H.P.S., Chaudhury P. ( Eds.), Nutrition in children: Developing country concerns, Cambridge Press, New Delhi, India, 1994, 492-524 p.

[165]Almeida C.A.N. de, Crott G.C., Ricco R.G., del Ciampo L.A., Dutra-de-Oliveira J.E., Cantolini A., Control of iron-deficiency anaemia in Brazilian preschool children using iron-fortified orange juice, Nutr. Res. 23 (2003) 27-33.

[166] Angeles-Agdeppa I., Magsadia C.R., Capanzana M.V., Fortified juice drink improved iron and zinc status of schoolchildren, Asia-Pac. J. Clin. Nutr. 20 (2011) 535-543.

[167]Tetens L., Alinia S., The role of fruit consumption in the prevention of obesity, J. Hortic. Sci. Biotech. 1 (2009) 47-51.

[168] McCrory M.A., Fuss P.J., Saltzman E., Roberts S.B., Dietary determinants of energy intake and weight regulation in health adults, J. Nutr. 130 (2000) 275-279.

[169] Nicklas T.A., O'Neil C.E., Kleinman R., Association between 100 per cent juice consumption and nutrient intake and weight of children aged 2 to 11 years, Arch. Pediat. Adol. Med. 162 (2008) 557-565.

[170] O'Neil C.E., Nicklas T.A., A review of the relationship between 100 per cent fruit juice consumption and weight in children and adolescents, Am. J. Lifestyle Med. 2 (2008) 315-354.

[171]Newby P.K., Peterson K.E., Berkey C.S., Leppert J., Willett W.C., Colditz G.A., Beverage consumption is not associated with changes in weight and body mass index among low-income preschool children in North Dakota, J. Am. Diet. Assoc. 104 (2004) 1086-1094.

[172] Fulgoni V., Consumption of fruit juice is not associated with being overweight in children, Exp. Biol. Abstr. 139 (2006) 114.

[173] Lim S., Sohn W., Burt B.A., Sandretto A.M., Kolker J.L., Marshall T.A., Ismail A.I., Cariogenicity of soft drinks, milk and fruit juice in low-income african-american children: a longitudinal study, J. Am. Dent. Assoc. 139 (2008) 959-967. 
[174] Moynihan P.J., The role of diet and nutrition in the etiology and prevention of oral disease, Bull. World Health Organ. 83 (2005) 1-5.

[175] Hannig C., Sorg J., Spitzmuller B., Hannig M., Al-Ahmad A., Polyphenolic beverages reduce initial bacterial adherence to enamel in situ, J. Dent. 37 (2009) 560-566.

[176] Ferrazzano G.F., Amato I., Ingenito A., De Natale A., Pollio A., Anti-cariogenic effects of polyphenols from plant stimulant beverages (cocoa, coffee, tea), Fitoterapia 80 (2009) 255-262.

[177]Davis J.R., Stegeman C.A., The dental hygienist guide to nutritional care, WB Saunders, Phila., U.S.A., 1998, 123 p.

[178]Fazeli M.R., Bahmani S., Jamalifar H., Samadi N., Effect of probiotication on antioxidant and antibacterial activities of pomegranate juices from sour and sweet cultivars, Nat. Prod. Res. 25 (2011) 288-290.
[179]Karapinar M., Sengun I.Y., Antimicrobial effect of koruk (unripe grape-Vitis vinifera) juice against Salmonella typhimurium on salad vegetables, Food Control 18 (2007) 702-706.

[180] Bhardwaj R.L., Mukherjee S., Effects of fruit juice blending ratios on kinnow juice preservation at ambient storage condition, Afr. J. Food Sci. 5 (2011) 281-286.

[181]Dennison B.A., Rockwell H.L., Baker S.L., Excess fruit juice consumption by preschool - aged children is associated with short stature and obesity, Pediatrics 99 (1997) 15-22.

[182] Dennison B.A., Fruit juice consumption by infants and children: a review, J. Am. Coll. Health 15 (1996) 4S-11S.

[183] Nandal U., Bhardwaj R.L., Role of fruit juices in nutritional and health security, Indian Food Pack. 67 (2013) 112-122.

\section{Compuestos bioactivos y propiedades medicinales de zumos de frutas.}

Resumen - El producto. Los zumos de frutas ocupan un lugar importante en las dietas modernas de personas pertenecientes a diferentes comunidades y clases en el mundo entero. Se trata de líquidos no fermentados, pero fermentables, extraídos de la parte comestible de las frutas sanas y suficientemente maduras y frescas. Compuestos bioactivos. Los zumos de frutas contienen nutrientes como las vitaminas, los elementos minerales, los oligoelementos, energía y compuestos fitoquímicos, que incluyen flavonoides, polifenoles y antioxidantes de los que se ha demostrado que presentan una variedad de ventajas saludables. Las propiedades medicinales. El modo de acción de los compuestos bioactivos a base de zumo de frutas parece estar, en la mayoría de los casos, relacionado con la modulación de las actividades de los genes. En el marco de una alimentación equilibrada, los zumos de frutas permiten a la vez gozar de una buena salud y limitar seriamente los riesgos de enfermedades; existe, por lo tanto, una fuerte demanda por parte de la medicina alternativa para luchar contra diferentes tipos de enfermedades, tales como las inflamaciones crónicas, artritis, diabetes, hipertensión arterial, dolores musculares, dolores menstruales, dolores de cabeza, enfermedades cardíacas, sida, cáncer, úlceras gástricas, esguinces, depresión, malas digestiones, arterioesclerosis, problemas sanguíneos y toxicomanía. Además, considerar los zumos de frutas como no-consumibles en el contexto de la obesidad y de la salud dental privaría al consumidor de un producto alimenticio perfectamente sano y nutritivo, y sería completamente contrario a las informaciones proporcionadas por la comunidad científica. Discusión y conclusión. Los zumos de frutas, consumidos moderadamente siguiendo ciertas recomendaciones, constituyen una excelente elección de bebida.

India / frutas / jugo de frutas / alimentos sanos / propiedades medicinales / antioxidantes / fitoquímica / resveratrol / sobrepeso 